DOI: 10.33766/2524-0323.90.267-278

УДК 343.985:343.132:343.575

О. В. Лащук,

головний інспектор управління протидії правопорушенням

у сфері легального обігу наркотиків Департаменту протидії наркозлочинності

Національної поліції України (м. Київ, Україна) e-mail:leoss@ukr.net iDhttps://orcid.org/0000-0002-9722-4443

\title{
ТИПОВІ СЛІДЧІ СИТУАЩЇ ПІД ЧАС ЗБУТУ НАРКОТИЧНИХ ЗАСОБІВ ТА ПСИХОТРОПНИХ РЕЧОВИН ІЗ ВИКОРИСТАННЯМ ІНТЕРНЕТ-МЕРЕЖІ
}

У статті здійснюється аналіз подання в наукових працях типових слідчих ситуацій, які виникають у разі виявлення слідчим факту збуту наркотичних засобів та психотропних речовин, що здійснюється з використанням інтернет-мережі.

У залежності від обставин виявлення факту незаконного збуту наркотичних засобів та психотропних речовин кожна типова слідча ситуащія поєднує в собі різноманітні компоненти, до яких належать процесуальний, організаційно-тактичний, інформаційний, тактичний та психологічний.

В основу класифікацій типових слідчих ситуацій покладено наявність або відсутність інформації, що має значення для розв'яння основних завдань розслідування, обсяг такої інформації та способи її отримання, що в подалышому впливає на подалыше розслідування кримінальних правопорушень.

Ключові слова: типова слідча ситуащія, незаконний збут наркотичних засобів та психотропних речовин, кримінальне провадження, слідчі (розшукові) дії, інтернет-мережа.

Постановка проблеми. Розглянувши статистичні дані щодо протидії наркозлочинності в Україні, ми переконливо можемо стверджувати про те, що наркозлочинність у нашій державі впевнено набирає сили, зростає та поширюється серед молодих людей та підлітків.

Так, за статистичними даними Офісу Генерального прокурора України, органами та підрозділами Національної поліції України лише в 2019 році зареєстровано 28,0 тис. кримінальних правопорушень, пов' язаних із незаконним обігом наркотичних засобів, психотропних речовин, їх аналогів та прекурсорів (ст. 305-320 КК України). Із незаконного обігу вилучено 4,7 тонн наркотичних засобів і психотропних речовин (серед яких 127 кг героїну, 9,8 кг кокаїну та 20,3 кг амфетамфінів), ліквідовано 103 підпільні нарколабораторії та 506 наркопритонів. Високий рівень споживання наркотичних засобів та психотропних речовин призводить до того, що ділки від наркобізнесу поширюють мережу збуту наркотичних засобів і психотропних речовин, залучаючи до споживання нових жертв. У 2019 році викрито та направлено до суду 6,1 тис. кримінальних проваджень, пов' язаних зі збутом наркотичних засобів і психотропних речовин (ст. 307 КК України) [1]. За вказаний період підрозділи про-

(C) Лащук О. В., 2020 
тидії наркозлочинності по всій державі викрили понад 300 кримінальних правопорушень щодо збуту наркотичних засобів та психотропних речовин із використанням інтернет-мережі [2].

В останні роки значно зросли масштаби незаконного обігу наркотичних засобів і психотропних речовин, які постали серйозною загрозою здоров'ю і благополуччю людей та набули транснаціонального характеру. Особлива небезпека полягає в тому, що організовані групи в процесі функціонування контролюють осіб, які самостійно вчиняли злочини, пов' язані з наркотичними засобами і психотропними речовинами, та встановлюють міцні організаційні зв' язки між собою, а також монополізують обіг указаних засобів та речовин на значних територіях.

Наркоділками відразу були позитивно оцінені технічні характеристики інтернет-мережі під час незаконного збуту наркотичних засобів і психотропних речовин:

- можливість знаходитись організаторам та координаторам таких кримінальних правопорушень у будь-якому місці та за будь-який час виходити на зв'язок зі співучасником, притому перебуваючи в цей час поза межами України, що значно ускладнює їх викриття та притягнення до кримінальної відповідальності;

- наявність так званих інтернет-пейджерів (наприклад, Telegram, Skype, ICQ, Miranda, QIP) та з анонімними акаунтами, дають можливість підтримувати зв' язок збувальника наркотичних засобів та психотропних речовин із їх продавцем без встановлення їхніх особистостей;

- використання Інтернет-мережі ускладнює пеленгацію та своєчасне встановлення місцезнаходження збувальника наркотичних засобів та психотропних речовин працівниками правоохоронних органів;

- особа, яка збуває наркотичні засоби чи психотропні речовини, має можливість підтримувати зв'язок з великою кількістю потенщійних покущців, що значно збільшує кримінальні прибутки, порівняно з традиційними способами збуту;

- відсутність реального, зокрема візуального, контакту між збувальником наркотичних засобів та психотропних речовин та їх покущем виключає можливість упізнання першого, що значно знижується небезпеку його викриттяйі ускладнює проведення в подалышому слідчих (розшукових) дій, спрямованих на впізнання злочинщя;

- розміщення збувальником в інтернет-мережі каталогу наркотичних засобів та психотропних речовин дає змогу легше та швидше реалізовувати заборонені засоби та речовини;

- виключається можливість нападу на збувальника з боку покупця з метою безоплатного заволодіння наркотичними засобами та психотропними речовинами $[3$, с. 3; 4].

Указані вище та інші обставини негативно впливають на планування й організацію розслідування розглядуваного виду кримінального правопорушення та висунення відповідних слідчих версій на початковому етапі його розслідування. Версії визначають не тільки напрямок розслідування, але й роблять його цілеспрямованим, забезпечують швидке і повне розкриття злочину. Системи типових версій визначають головні напрями діяльності слідчого, специфіку завдань, що піллягають розв'язанню. Тому версії мають бути фактично обгрунтованими і обов'язково реально перевіреними й чітко сформульованими. 
Швидке та оперативне здійснення слідчих (розшукових) та негласних слідчих (розшукових) дій (далі - НСРД) за фактами вчинення незаконних дій з наркотичними засобами та психотропними речовинами з використанням інтернет-мережі $є$ запорукою відновлення порушених злочином суспільних відносин, притягнення винних осіб до суворої відповідальності. Причому недостатня обізнаність слідчих про різновиди типових слідчих ситуацій та відповідних їм слідчих версій призводить до погіршення ефективності початкового етапу розслідування, через неправильне визначення напрямів розслідування, вибору комплексу слідчих дій, що обумовлює актуальність даної статті.

Аналіз останніх досліджень і публікацій. Необхідність вдосконалення механізму протидії наркозлочинності об'єднує науковців і практиків. Дослідженню типових слідчих ситуацій при розслідуванні незаконного збуту наркотичних засобів та психотропних речовин присвятили свої праці Л. В. Борисова, К. Л. Бугайчук, А. В. Волобуєв, В. А. Коршенко, І. В. Кузьмічова-Кисленко, Т. П. Матюшкова, С. В. Мокляк, Н.О.Прібиткова, О. В. Одерій, О. О. Савченко, А. П. Сакаль, О. А. Самойленко, Р. Л. Степанюк, О. М. Стрілыців, О. Ю. Татаров, В. Б. Школьний, О. О. Юхно тощо.

Формулювання цілей. Метою даної статті є визначення типових слідчих ситуацій при збуті наркотичних засобів та психотропних речовин із використанням інтернет-мережі.

Виклад основного матеріалу. У теорії криміналістики панує різноманіття поглядів на зміст поняття та видів «слідча ситуація», що нерозривно пов' язане з проблемою підвищення ефективності розслідування злочинів. Одним із перших визначення даному поняттю дав О. Н. Колесніченко ще в 1967 році, окресливши цю категорію як певній стан у розслідуванні злочинів, що характеризується наявністю доказів, інформаційного матеріалу та пов'язаними 3 ним конкретними завданнями щодо його збирання й перевірки. У своїх роботах автор не лише сформулював поняття слідчої ситуації, але й правильно намітив подальший шлях розвитку даного компонента структури методики розслідування [5, с. 11].

Своєю чергою, М. В. Салтевський зазначає, що слідча ситуація - це сукупність обставин конкретної події злочину, актуалізованих слідчим, прокурором, судом, що здійснюють його розкриття, розслідування й попередження, або це сукупність актуалізованої суб'єктом кримінального процесу потенщійної інформації про злочин, що відображена та зберігається в матеріальному середовищі [6, с. 214].

В. В. Логінова визначає слідчу ситуащії як сукупність обставин, що сформувалась на певному етапі розслідування на підставі фактичних даних про подію злочину, яка зумовлює можливість органів досудового слідства реалізувати свої можливості щодо розкриття, розслідування та попередження злочину [7, с. 282].

У своїй дисертації С. В. Веліканов робить висновки, що вивчення змісту і структури слідчої ситуащії дає підстави для висновку про ії криміналістичну сутність, що виявляється в специфічності обстановки й стану в провадженні як окремих слідчих дій, так і етапів, а також розслідування загалом, залежно від цього вимагає прийняття рішень тактико-криміналістичного чи методико-криміналістичного характеру. Учений визначає слідчу ситуацію як сукупність сформованих на певному етапі умов - стану й обстановки розслідування, що сприймає, оцінює та використовує слідчий 
для виконання тактичних завдань і досягнення загальних (стратегічних) цілей розслідування [8, с. 9].

Аналізуючи роботи з методик розслідування злочинів окремих видів, Л. В. Борисова, прийшла до обгрунтованого висновку про те, що типові слідчі ситуації, як правило, використовуються на початковому й наступному етапі розслідування та дозволяють:

- правиљьо визначити фактичне положення тих чи інших обставин у процесі розслідування, маючи на меті отримання даних для прийняття стратегічних і тактичних рішень у справі;

- висунути найбілыш обгрунтовані слідчі версії та визначити подалыший хід розслідування в найбільш перспективному напрямку;

- намітити повний перелік слідчих дій та їхній найбільш доцільний порядок 3 метою об'єктивного розслідування злочину;

- звести до мінімуму число рішень слідчого, що грунтуються на пробах та помилках [9, с. 98].

Що стосується визначення часових рамок початкового етапу розслідування, то в даному випадку ми погоджуємося з висновками О. А. Самойленка, який їх визначає з моменту внесення інформації про злочин у СРДР до моменту висунення принаймні одній особі законної й обгрунтованої підозри у вчиненні кримінального правопорушення (одного або декількох) [10, с. 207-208].

Незважаючи на неоднаковість поглядів учених-криміналістів на визначення поняття слідчої ситуащії, ця категорія криміналістичної тактики вже цупко увійшла до слідчої практики. Так у методичних рекомендаціях «Кваліфікація та розслідування злочинів, пов'язаних із незаконним збутом наркотичних засобів, психотропних речовин, їх аналогів та прекурсорів за допомогою мережі Інтернет» (НАВС, 2012) О. М. Стрільців, з огляду на специфіку вчинення вказаного виду злочину, визначає лише одну слідчу ситуацію - безпосереднє виявлення органом дізнання ознак збуту наркотичних засобів та психотропних речовин, що здійснюється за допомогою інтернет-мережі[3, с. 9].

А. П. Сакаль, здійснюючи дослідження проблем розслідування транснаціональних організованих злочинних угруповань, визначає три слідчі ситуащії на початковому етапі розслідування вказаної категорії злочинів, зокрема:

- перша характеризується наявністю в слідчого оперативної інформації про здійснення організованим злочинним угрупуванням обігу наркотичних засобів та психотропних речовин на території кількох держав (наявності інших ознак транснаціонального характеру). Причому конкретні особи, які вчинюють злочинні дії, не встановлені, але дослідження різних джерел інформації дозволяють зробити щодо них обгрунтовані припущення;

- друга слідча ситуація характеризується білышим обсягом інформації щодо організованого злочинного угрупування, що здійснює транснаціональний обіг наркотичних засобів та психотропних речовин. Незважаючи на те, що всіх осіб - членів злочинного угруповання ще не встановлено, слідчий має конкретні дані щодо їх окремих членів, про злочинну діяльність свідчить наявна в кримінальному провадженні доказова та орієнтуюча інформація, отримана із різних джерел; 
- третя ситуація має ще більшу інформаційну визначеність щодо осіб, які реалізують злочинну діяльність із транснаціонального обігу наркотичних засобів та психотропних речовин. Це може виявлятися в затриманні всіх або окремих членів злочинного угрупування під час підготовки, вчинення чи приховування злочинів. Подібна ситуація є сприятливою для досудового розслідування, адже характеризується найбільшою інформаційною визначеністю, можливістю проводити слідчі (розшукові) дії, які безпосередньо доводять причетність винних осіб до вчинення злочинів [11, с. 171-172].

У науково-методичних рекомендаціях «Особливості досудового розслідування незаконного виробнищтва, виготовлення, придбання, зберігання, перевезення, пересилання чи збуту наркотичних засобів, психотропних речовин або їх аналогів (в умовах нового кримінального процесуального та оперативно-розшукового законодавства)» (ХНУВС, 2015) запропоновано наступні дві слідчі ситуації:

1). Підозрюваного затримано під час або відразу після вчинення ним протиправних дій з наркотичними засобами та психотропними речовинами: а) виявлені наркотичні засоби та психотропні речовини придбано підозрюваним у невідомого йому іншого продавця; б) підозрюваний - постійний клієнт у знайомого йому збувальника; в) підозрюваний виготовляє наркотичні засоби та психотропні речовини з метою збуту із придбаної, добутої або самостійно вирощеної ним наркосировини; г) затримана особа є членом злочинного угруповання, що займається наркобізнесом; д) виявлені в підозрюваного наркотичні засоби викрадено з лікувального закладу, аптеки, іншої медичної установи ним самим або іншою особою.

2). Кримінальне провадження розпочато у зв' язку з повідомленням про викрадення партії наркотиковмісних препаратів із приміщення аптеки (хімфармпідприємства, медичної установи) [12, с. 27-28].

О. В. Одерій у підручнику «Криміналістика» (ХНУВС, 2018) [13, с. 234-237] та спільно з колективом авторів у методичних рекомендаціях «Особливості розслідування незаконного виробництва, виготовлення, придбання, зберігання, перевезення, пересилання чи збуту наркотичних засобів, психотропних речовин або їх аналогів» (ХНУВС, 2017) [14, с. 14-17], окреслює наступні типові ситуації, що виникають під час відкриття кримінального провадження злочинів зазначеної категорії:

1). Орган досудового розслідування (прокурор) отримує повідомлення від оперативного підрозділу про виявлені ним ознаки злочину (ст. 305-322 КК України), але оперативно-розшукові заходи ще тривають, i їх припинення може негативно вплинути на результати кримінального провадження (ст. 7 п. 7 Закону України «Про оперативно-розшукову діяльність»).

2). Орган досудового розслідування отримує відомості про ознаки злочину (заяву, повідомлення), але не було затримання й, відповідно, відсутній предмет злочину.

3). Орган досудового розслідування (прокурор) або безпосередньо працівник правоохоронного органу самостійно виявили відомості про ознаки злочину, зловмисника затримали з предметом злочину.

У подальшому в науково-методичних рекомендаціях «Особливості розслідування злочинів, пов' язаних із незаконним обігом наркотичних засобів чи психотропних речовин із використанням сучасних телекомунікаційних та інших технологій» 
(2019), підготовлених авторським колективом Харківського національного університету внутрішніх справ, зокрема О. О. Юхно, Т. П. Матюшковою, В. А. Коршенко та іншими, пропонуються вже наступні слідчі ситуації:

1). Незаконний обіг наркотичних засобів та психотропних речовин із використанням інтернет-мережі відбувся, відомі певні відомості про особу збувальника.

2). Має місце систематичний збут наркотичних засобів та психотропних речовин із використанням інтернет-мережі, інформація про збувальника незначна або відсутня [15, с. 19-20].

О. М. Стрільців у посібнику «Розслідування незаконного збуту наркотичних засобів та психотропних речовин» (НАВС, 2019), на мій погляд, білыш конструктивно визначає наступні типові слідчі ситуації:

1). Підозрюваного затримано з наркотичними засобами та/або психотропними речовинами у великій кількості, у т.ч. під час їх виготовлення, перевезення або пересилання. Інформація про обставини вчинення цього кримінального правопорушення відсутня.

2). У територіальному органі Національної поліції зареєстровано повідомлення (заяву) про факти незаконного виробництва, виготовлення, придбання, зберігання, перевезення, пересилання з метою збуту та/або збут наркотичних засобів та/чи психотропних речовин або про самостійне виявлення кримінального правопорушення оперативним підрозділом, пов' язаного з незаконним виробнищтвом, виготовленням, придбанням, зберіганням, перевезенням, пересиланням з метою збуту та/або збуту наркотичних засобів та/чи психотропних речовин. Інформація про осіб, які можуть бути причетні до вказаних злочинів, відома або відома частково.

3). Під час кримінального провадження, відкритого за фактом вчинення злочинів у сфері обігу наркотичних засобів, психотропних речовин та прекурсорів, отримана інформація про осіб, причетних до незаконного виробнищтва, виготовлення, придбання, зберігання, перевезення, пересилання з метою збуту та/або збут наркотичних засобів та/чи психотропних речовин [16, с. 29-34].

Заразом на основі власного досвіду роботи в підрозділах протидії наркозлочинності Національної поліції України, а також за результатами вивчення слідчої практики, можна виділити слідчі ситуащії, які, на погляд автора статті, складаються на початковому етапі розслідування злочинів, учинених організованими злочинними угрупованнями, що здійснюють свою протиправну діяльність у сфері збуту наркотичних засобів та психотропних речовин із використанням інтернет-мережі. Їх можна умовно поділити на декілька видів, залежно від характеру первинної інформації про подію і його учасників.

1). Працівниками поліції затримано за незаконне зберігання наркотичних засобів та психотропних речовин особу, від якої в подальшому під час проведення щодо неї слідчих (розшукових) дій надходить інформація про:

- існування злочинного угруповання, яке здійснює збут наркотичних засобів та психотропних речовин шляхом так званих закладок;

- зв'язок під час придбання/збут наркотичних засобів та психотропних речовин здійснюється через так звані інтернет-пейджери (наприклад, Telegram, Skype, ICQ, Miranda, QIP); 
- у наявності є попередня інформація лише про акаунт сторінки користувача соціальної мережі або програмного забезпечення (Telegram, Twitter, Viber, WhatsApp) або інших закритих для спілкування (DarkNet, Tor, I2P), а також про способи спілкування з ним;

- установчі дані осіб, які причетні до збуту наркотичних засобів та психотропних речовин затриманому не відома, як і їхні телефонні номери;

- затриманий - «постійний» клієнт, придбав таким чином декілька місяців поспіль;

- затриманому може бути відомо ще декілька осіб, які придбають наркотичних засобів та психотропних речовин у членів вказаного угруповання таким же способом;

- на співпрацю 3 правоохоронними органами з метою викриття злочинного угруповання затримана особа не погоджується.

2). Працівниками поліції випадково затримано особу, яка здійснювала постановку так званих закладок наркотичних засобів та психотропних речовин і у якої виявлено та вилучено декілька готових до збуту упаковок зі вказаними речовинами або засобами, при тому:

- затриманий відмовляється від співпраці із правоохоронними органами 3 метою викриття членів злочинного наркоугруповання;

- інформація про місце придбання наркотичних засобів та психотропних речовин відсутня, як і установчі дані про спільників затриманої особи.

3). До керівника слідчого підрозділу регіонального органу Національної поліції від підрозділу ДНДЕКЦ при МВС України надійшла інформація, що за результатами вивчення направлених до Каталогу наркотичних засобів, психотропних речовин, ïx аналогів та прекурсорів зразків, вилучених із незаконного обігу наркотичних засобів та психотропних речовин, у регіоні існує організоване злочинне наркоугруповання, про що засвідчують наступні факти:

- у регіоні здійснюється збут однотипних за хімічним складом та фізичною будовою наркотичних засобів та психотропних речовин;

- розповсюдження має поширений характер, про що засвідчує значна кількість направлених до Каталогу наркотичних засобів, психотропних речовин, їх аналогів та прекурсорів ДНДЕКЦ при МВС України зразків, вилучених із незаконного обігу наркотичних засобів та психотропних речовин протягом останнього періоду.

4). За результатами проведених оперативно-розшукових заходів оперативним підрозділом Національної поліції України реєструється повідомлення за фактом існування в регіоні злочинного угруповання, члени якого причетні до незаконного збуту наркотичних засобів та психотропних речовин. Причому, оперативний підрозділ припиняє проведення оперативно-розшукових заходів, і в подальшому може здійснювати лише НСРД лише на підставі письмового доручення слідчого чи прокурора. Заразом оперативний підрозділ - ініціатор розробки - може надати слідчому інформацію про:

- способи збуту наркотичних засобів та психотропних речовин шляхом так званих закладок; 
- про акаунт сторінки користувача соціальної мережі, через який підтримується зв' язок з особами, які здійснюють придбання/ збут наркотичних засобів та психотропних речовин;

- установчі дані інших осіб, які причетні до придбання/збуту наркотичних засобів та психотропних речовин затриманому;

- місця незаконного виготовлення та зберігання призначених для збуту наркотичних засобів та психотропних речовин.

5. За результатами реалізації оперативно-розшукових заходів слідчий відкриває кримінальне провадження, у ході якого вже затримується особа під час придбання або зберігання наркотичних засобів та психотропних речовин. Таке затримання здійснюється з метою проведення вже в межах кримінального провадження подалыших необхідних процесуальних дій слідчим, направлених на викриття інших членів організованого злочинного наркоугруповання. При тім оперативний підрозділ може надати слідчому інформацію про: вання;

- участь затриманої особи в структурі діяльності злочинного наркоугрупо-

- способизбуту наркотичних засобів та психотропних речовин шляхом так званих закладок;

- про акаунти та сторінки соціальної мережі, через який підтримується зв' язок з особами, які здійснюють придбання/збут наркотичних засобів та психотропних речовин;

- установчі дані інших осіб, які причетні до придбання та збуту наркотичних засобів та психотропних речовин;

- місця незаконного виготовлення та зберігання призначених для збуту наркотичних засобів та психотропних речовин.

Висновки. Дослідження проблематики типових слідчих ситуащій стосовно розслідування розповсюдження наркотичних засобів та психотропних речовин із використанням інтернет-мережі має велике значення для розроблення криміналістичної методики розслідування вказаних видів злочинів. На нашу думку, типові слідчі ситуації, які були запропоновані, сприятимуть оптимізації слідчої діяльності, зниженню латентності аналізованого злочину, а також активізації наукового пошуку з даного, безумовно, актуального напряму дослідження.

\section{Використані джерела:}

1. Про зареєстровані кримінальні правопорушення та результати їх досудового розслідування. Статистична інформація за 2019 рік. Офіс Генерального прокурора. Офіційний вебсайт. URL:https://www.gp.gov.ua/ua/1stat.

2. Про результати протидії наркозлочинності на території України за 2019 рік. Аналітичний огляд. Департамент протидії наркозлочинності Національної поліції. 2020. 7 с.

3. Татаров О. Ю., Стрільців О. М., Школьний В. Б. та ін. Кваліфікація та розслідування злочинів, пов' язаних із незаконним збутом наркотичних засобів, психотропних речовин, їх аналогів та прекурсорів за допомогою мережі інтернет: метод. реком. Київ: ГСУ МВС України, Нац. акад. внутр. справ. 2012. 30 с.

4. Лапта С. П. Використання Інтернету, як інструменту незаконного продажу наркотичних засобів та сильнодіючих речовин. Тези доповідей міжнародної науково-практи- 
чної конференщії «Сучасні тенденції розвитку криміналістики та кримінального процесу», до 100-річчя від дня народження професора М. В. Салтевського.(м. Харків, 8 листопада 2017 р.) / МВС України, Харків. нац. ун-т внутр. Справ. Харків, 2017. С. 114-116.

5. Колесниченко А. Н. Научные иправовые основы расследования отдельных видов преступлений: автореф. дис. ... доктора юрид. наук: спец. 12.00 .09 «Уголовный процесс и криминалистика; судебная экспертиза». Харків, 1967.38 с.

6. Салтевський М. В. Криміналістика: підручник: у 2 ч. Ч. 2. Харків: Консум, 2001. 528 с.

7. Логінова В. В. Поняття та значення слідчих ситуацій у методищі розслідування злочинів. Форум права. 2010. №3. С. 278-283.

8. Веліканов С. В. Класифікація слідчих ситуацій у криміналістичній методиці: автореф. дес. ... канд. юрид. наук.: спец. 12.00 .09 «Кримінальний процес та криміналістика ; судова експертиза». Харків, 2002. 22 с.

9. Борисова Л. В. Типові слідчі ситуації при розслідуванні розкрадань наркотичних засобів, психотропних речовин, ïх аналогів або прекурсорів. Форум права. 2011. № 2. С. 97102.

10. Самойленко О. А. Основи методики розслідування злочинів, вчинених у кіберпросторі: монографія; за заг. ред. А. Ф. Волобуєва. Одеса: ТЕС, 2020.372 с.

11. Сакаль А. П. Типові слідчі ситуації початкового етапу розслідування злочинів у сфері обігу наркотичних засобів, вчинених транснаціональними організованими злочинними угрупуваннями. Криминалистика и судебная экспертиза. 2014. Вып. 59. С. 168-177.

12. Бугайчук К. Л., Савченко О. О. Прібиткова Н. О. Особливості досудового розслідування незаконного виробництва, виготовлення, придбання, зберігання, перевезення, пересилання чи збуту наркотичних засобів, психотропних речовин або їх аналогів (в умовах нового кримінального процесуального та оперативно-розшукового законодавства): наук.-метод. реком. Харків, Харків. нац. ун-т внутр. справ. 2015. 99 с.

13. Волобуєв А. Ф., Одерій О. В., Степанюк Р. Л. та ін. Криміналістика: підручник: у 2 т., Т. 2; за заг. ред. А. Ф. Волобуєва, Р. Л. Степанюка, В. О. Малярової; МВС України, Харків. нац. ун-т внутр. справ. Харків, 2018. 312 с.

14. Особливості розслідування незаконного виробнищтва, виготовлення, придбання, зберігання, перевезення, пересилання чи збуту наркотичних засобів, психотропних речовин або їх аналогів: Методичні рекомендації для практичних підрозділів Національної поліції України. Харків, Харків. нац. ун-т внутр. справ. 2017. 76 с.

15. Юхно О. О., Матюшкова Т. П., Коршенко В. А. та ін. Особливості розслідування злочинів, пов'язаних із незаконним обігом наркотичних засобів чипсихотропних речовин із використанням сучасних телекомунікаційних та інших технологій: наук.-метод. рек.; за заг. ред. д. ю. наук, професора О. О. Юхна. [Серія «Бібліотечка слідчого і детектива: проблеми кримінального процесу»]. На замовлення Головного слідчого управління Національної поліпії України. Харків, Харків. нац. ун-т внутр. справ. 2019. 48 с.

16. Стрільців О. М., Кузьмічова-Кисленко І. В., Лащук О. В. та ін. Розслідування незаконного збуту наркотичних засобів та психотропних речовин: посібник. Київ, Нац. акад. внутр. справ, 2019. 135 с.

\section{References:}

1. Pro zareyestrovani kryminal'ni pravoporushennya ta rezul'taty yikh dosudovoho rozsliduvannya. Statystychna informatsiya za 2019 rik. Ofis Heneral'noho prokurora. Ofitsiynyy veb-sayt. (2019) N. p. URL:https:/ / www.gp.gov.ua/ua/1stat. [in Ukrainian]. 
4. Pro rezul'taty protydiyi narkozlochynnosti na terytoriyi Ukrayiny za 2019 rik. Analitychnyy ohlyad. (2020) N. p. Departament protydiyi narkozlochynnosti Natsional'noyi politsiyi. [in Ukrainian].

3. Tatarov, O. YU., Stril'tsiv, O. M., Shkol'nyy, V. B. et al. (2012) Kvalifikatsiya ta rozsliduvannya zlochyniv, pov"yazanykh iz nezakonnym zbutom narkotychnykh zasobiv, psykhotropnykh rechovyn, yikh analohiv ta prekursoriv za dopomohoyu merezhi Internet: metod. rekom. Kyiv: HSU MVS Ukrayiny, Nats. akad. vnutr. sprav. [in Ukrainian].

4. Lapta, S. P. (2017) Vykorystannya Internetu, yak instrumentu nezakonnoho prodazhu narkotychnykh zasobiv ta syl'nodiyuchykh rechovyn. Tezy dopovidey mizhnarodnoyi naukovopraktychnoyi konferentsiyi «Suchasni tendentsiyi rozvytku kryminalistyky ta kryminal'noho protsesu», do 100-richchya vid dnya narodzhennya profesora M. V. Saltevs'koho. (m. Kharkiv, 8 lystopada 2017 r.) - Abstracts of the international scientific-practical conference "Modern trends in the development of criminology and criminal procedure", to the 100th anniversary of the birth of Professor MV Saltevsky. (Kharkov, November 8, 2017)/MVS Ukrayiny, Kharkiv. nats. un-t vnutr. Sprav. Kharkiv, 114-116. [in Ukrainian].

5. Kolesnychenko, A. N. (1967) Nauchnye y pravovye osnovy rassledovanyya otdel'nykh vydov prestuplenyy. Extended abstract of Doctor's thesis. Kharkiv. [in Ukrainian].

6. Saltevs'kyy, M. V. (2001) Kryminalistyka: pidruchnyk (Part.1-2; part. 2) Kharkiv: Konsum. [in Ukrainian].

7. Lohinova, V. V. (2010) Ponyattya ta znachennya slidchykh sytuatsiy u metodytsi rozsliduvannya zlochyniv. Forum prava-Law Forum, 3, 278-283. [in Ukrainian].

8. Velikanov, C. V. (2002) Klasyfikatsiya slidchykh sytuatsiy u kryminalistychniy metodytsi. Kharkiv. [in Ukrainian].

9. Borysova, L. V. (2011) Typovi slidchi sytuatsiyi pry rozsliduvanni rozkradan' narkotychnykh zasobiv, psykhotropnykh rechovyn, yikh analohiv abo prekursoriv. Forum prava - Law Forum, 2, 97-102. [in Ukrainian].

10. Samoylenko, O. A. (2020) Osnovy metodyky rozsliduvannya zlochyniv, vchynenykh u kiberprostori: monohrafiya; A. F. Volobuyev (Ed.). Odesa: TES. [in Ukrainian].

11. Sakal', A. P. (2014) Typovi slidchi sytuatsiyi pochatkovoho etapu rozsliduvannya zlochyniv $\mathrm{u}$ sferi obihu narkotychnykh zasobiv, vchynenykh transnatsional'nymy orhanizovanymy zlochynnymy uhrupuvannyamy. Krymynalystyka y sudebnaya ékspertyza Forensics and forensics, 59, 168-177. [in Ukrainian].

12. Buhaychuk, K. L., Savchenko, O. O., Pribytkova, N. O. (2015) Osoblyvosti dosudovoho rozsliduvannya nezakonnoho vyrobnytstva, vyhotovlennya, prydbannya, zberihannya, perevezennya, peresylannya chy zbutu narkotychnykh zasobiv, psykhotropnykh rechovyn abo yikh analohiv (v umovakh novoho kryminal'noho protsesual'noho ta operatyvno-rozshukovoho zakonodavstva): nauk.-metod. rekom. Kharkiv, Kharkiv. nats. un-t vnutr. sprav. [in Ukrainian].

13. Volobuyev, A. F., Oderiy, O. V., Stepanyuk, R. L. et al. (2018) Kryminalistyka: pidruchnyk. (Vol.1-2; Vol. 2) A. F. Volobuyev, R. L. Stepanyuk, V. O. Malyarova (Eds.) MVS Ukrayiny, Kharkiv. nats. un-t vnutr. sprav. Kharkiv. [in Ukrainian].

14. Osoblyvosti rozsliduvannya nezakonnoho vyrobnytstva, vyhotovlennya, prydbannya, zberihannya, perevezennya, peresylannya chy zbutu narkotychnykh zasobiv, psykhotropnykh rechovyn abo yikh analohiv. (2017) Metodychni rekomendatsiyi dlya praktychnykh pidrozdiliv Natsional'noyi politsiyi Ukrayiny. Kharkiv, Kharkiv. nats. un-t vnutr. sprav. [in Ukrainian].

15. Yukhno, O. O., Matyushkova, T. P., Korshenko, V. A. et al. (2019) Osoblyvosti rozsliduvannya zlochyniv, pov'yazanykh iz nezakonnym obihom narkotychnykh zasobiv chy psykhotropnykh rechovyn iz vykorystannyam suchasnykh telekomunikatsiynykh ta inshykh tekhnolohiy: nauk.-metod. rek. O. O. Yukhno (Ed.). «Bibliotechka slidchoho i detektyva: problemy kryminal'noho protsesu»; na zamovlennya Holovnoho slidchoho upravlinnya 
Natsional'noyi politsiyi Ukrayiny. Kharkiv, Kharkiv. nats. un-t vnutr. sprav. [in Ukrainian].

16. Stril'tsiv, O. M., Kuz'michova-Kyslenko, I. V., Lashchuk, O. V. et al. (2019) Rozsliduvannya nezakonnoho zbutu narkotychnykh zasobiv ta psykhotropnykh rechovyn: posibnyk. Kyiv, Nats. akad. vnutr. sprav. [in Ukrainian].

Стаття надіӥшла до редколегї 03.09.2020

Лащук Е. В., главный инспектор управления противодействия в сфере легального оборота наркотиков Департамента противодействия наркопреступности Национальной полиции Украины

(г. Киев, Украина)

\section{ТИПИЧНЫЕ СЛЕДСТВЕННЫЕ СИТУАЦИИ ВО ВРЕМЯ СБЫТА НАРКОТИЧЕСКИХ СРЕДСТВ И ПСИХОТРОПНЫХ ВЕЩЕСТВ С ИСПОЛЬЗОВАНИЕМ ИНТЕРНЕТ-СЕТИ}

В статье проводится анализ представления в научных трудах типичных следственных ситуаций, возникающих в случае обнаружения следователем факта сбыта наркотических средств и психотропных веществ с использованием интернет-сети.

В зависимости от обстоятельств выявления факта незаконного сбыта наркотических средств и психотропных веществ каждая типичная следственная ситуация сочетает в себе различные компоненты, к которым относятся процессуальный, организационно-тактический, информационный, тактический и психологический.

В основу классификации типичных следственных ситуаций положено наличие или отсутствие информации, имеющей значение для решения основных задач расследования, объем такой информации и способы ееполучения, что в дальнейшем влияет на дальнейшее расследование уголовных правонарушений.

Ключевые слова: типичная следственная ситуация, незаконный сбыт наркотических средств и психотропных веществ, уголовное производство, следователи (розыскные) действия, интернет-сеть.

\section{Lashchuk O.,}

Chief Inspector of the Department for Combating Crime in the Sphere of Legal Drug Trafficking of the Department for Counteraction drug crime National Police of Ukraine (Kyiv, Ukraine)

\section{TYPICAL INVESTIGATIVE SITUATIONS DURING SALE OF DRUGS AND PSYCHOTROPIC SUBSTANCES USING THE INTERNET}

Considering the statistics on combating drug crime in Ukraine, we can convincingly say that drug crime in our country is confidently gaining strength, growing and spreading among young people and adolescents.

The article analyzes the presentation in scientific works of typical investigative situations that arise when an investigator discovers the fact of sale of narcotic drugs and psychotropic substances, which is carried out using the Internet. 
Depending on the circumstances of detection of the fact of illegal sale of narcotic drugs and psychotropic substances, each typical investigative situation combines various components, which include procedural, organizational-tactical, informational, tactical and psychological.

The classifications of typical investigative situations are based on the presence or absence of information relevant to the main tasks of the investigation, the amount of such information and methods of obtaining it, which further affects the further investigation of criminal offenses.

The study of the problems of typical investigative situations related to the investigation of the distribution of narcotic drugs and psychotropic substances using the Internet is of great importance for the development of forensic methods of investigating these types of crimes. In our opinion, the typical investigative situations that have been proposed will help to optimize investigative activities, reduce the latency of the analyzed crime, as well as intensify scientific research in this, of course, relevant area of research.

Keywords: typical investigative situation, illegal sale of narcotic drugs and psychotropic substances, criminal proceedings, investigative (search) actions, Internet network.

\section{DOI: 10.33766/2524-0323.91.278-285} УДК 343.98

\section{В. М. Плетенець,} кандидат юридичних наук, доцент, доцент кафедри криміналістики, судової медицини та психіатрії Дніпропетровського державного університету внутрішніх справ

(м. Дніпро, Україна) e-mail: viktor_plet@i.ua iDhttps://orcid.org/0000-0002-3619-8624

\section{ДЕЯКІ АСПЕКТИ ЗАБЕЗПЕЧЕННЯ БЕЗПЕКИ ОСІБ В УМОВАХ ПРОТИДІЇ ДОСУДОВОМУ РОЗСЛДУВАННЮ}

Стаття присвячена розгляду окремих аспектів забезпечення безпеки осіб в умовах протидії досудовому розслідуванню. У роботі наголошується, що однією з причин сформованої криміногенної обстановки є тиск на учасників кримінального провадження. Звертається увага, що, наприклад, так звані добросовісні учасники (свідки, потерпілі, співучасники), відчуваючи загрозу безпеці власній або близьким, можуть відмовлятися від раніше даних свідчень, змінювати їх, уникати явки до правоохоронних органів, залишати місце постійного мешкання тощо. Наголошується, що між кількістю отримуваної в ході розслідування інформації та відчуттям захищеності відповідним учасником провадження може бути простежена пряма залежність.

Ключові слова: учасники провадження, заходи забезпечення безпеки, тиск, протидія розслідуванню.

Постановка проблеми. Протиправний вплив із боку зацікавлених осіб на учасників провадження визнається найбілыш розповсюдженим засобом підриву системи кримінального правосуддя. Ще Г. Грос звертав увагу на наявність протидії розслідуванню, зокрема, шляхом давання неправдивих показань, удаваності з боку обвинува-

() Плетенець В. М., 2020 